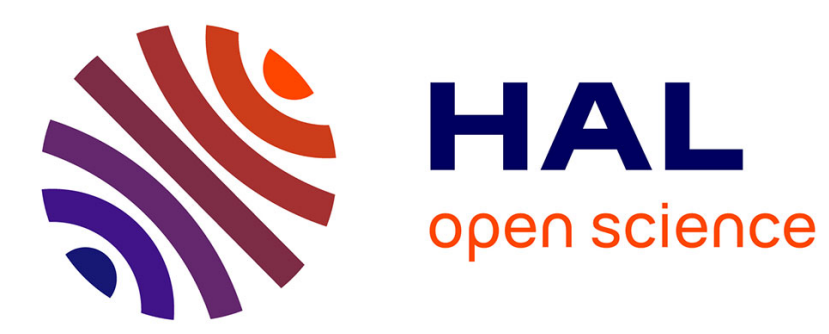

\title{
Factors controlling in vitro development of sunflower embryos ( 1) (2)
}

\author{
Anne Espinasse, Charles Lay, C. Dean Dybing
}

\section{To cite this version:}

Anne Espinasse, Charles Lay, C. Dean Dybing. Factors controlling in vitro development of sunflower embryos ( 1) (2). Agronomie, 1985, 5 (9), pp.825-832. hal-00884818

\section{HAL Id: hal-00884818 https://hal.science/hal-00884818}

Submitted on 1 Jan 1985

HAL is a multi-disciplinary open access archive for the deposit and dissemination of scientific research documents, whether they are published or not. The documents may come from teaching and research institutions in France or abroad, or from public or private research centers.
L'archive ouverte pluridisciplinaire HAL, est destinée au dépôt et à la diffusion de documents scientifiques de niveau recherche, publiés ou non, émanant des établissements d'enseignement et de recherche français ou étrangers, des laboratoires publics ou privés. 


\title{
Factors controlling in vitro development of sun- flower embryos $\left({ }^{1}\right)\left({ }^{2}\right)$
}

\author{
Anne ESPINASSE, Charles LAY \& C. Dean DYBING $\left({ }^{3}\right)$ \\ South Dakota State University, Brookings, South Dakota 57007, U.S.A.
}

SUMMARY

\begin{abstract}
Embryos of sunflower (Helianthus annuus L.) ranging in age from 3 days $(0.1 \mathrm{~mm}$ long) to 14 days $(7 \mathrm{~mm}$ long) post pollination were grown on HD, a formulation of MURASHIGE \& SKOOG's medium defined by HUFF \& DYBING (1980) and on B5, GAMBORG's medium (1968). Embryos smaller than $2 \mathrm{~mm}$ long without fully developed cotyledons, i.e. younger than 5 to 7 days old, could not grow on HD but grew relatively well on B5. Each component of HD was in turn altered so as to be identical to B5 and HD, and sunflower embryos within the same range of developmental stages were grown. It appeared that small young embryos (less than $2 \mathrm{~mm}$ without developed cotyledons) required a high sucrose concentration $(9 \%)$ and a low nitrogen content. The best form of nitrogen supply $\left(\mathrm{NH}_{4}\right.$ or $\mathrm{NO}_{3}$ ) could not be identified. High sucrose and inositol concentrations inhibited root formation. Embryos had to be transferred to a rooting medium before transplantation to a greenhouse. Only 10 to $20 \%$ of the small embryos (less than $2 \mathrm{~mm}$ when plated) and at most $59 \%$ of the large embryos (more than $2 \mathrm{~mm}$ when plated) produced adult plants through the whole in vitro procedure.
\end{abstract}

Additional key words : Embryo culture, sunflower, Helianthus annuus $L$., in vitro culture.

Facteurs contrôlant le développement in vitro des embryons de tournesol.

Des embryons de tournesol (Helianthus annuus L.) âgés de 3 jours (soit $0,1 \mathrm{~mm}$ de long environ) à 14 jours (soit $7 \mathrm{~mm}$ de long environ) à compter de la pollinisation ont été cultivés in vitro sur HD, une formulation du milieu de Murashige \& Skoog établie par Huff \& Dybing (1980) et sur B5, le milieu de Gamborg (1968). Les embryons de moins de $2 \mathrm{~mm}$ de long et sans cotylédon développé au moment de la mise en culture sont incapables de se développer sur HD mais au contraire croissent relativement bien sur B5. Chacun des constituants de HD a tour à tour été modifié de façon que HD et B5 soient identiques pour ce constituant. Des embryons représentant la même gamme de développement ont alors été mis en culture. Les embryons de moins de $2 \mathrm{~mm}$ et sans cotylédon développé requièrent une forte pression osmotique, assurée par la forte concentration en saccharose $(9 \mathrm{p}$. 100) associée à une concentration en azote relativement peu élevée en comparaison pour se développer in vitro. La meilleure forme sous laquelle fournir l'azote n'a pu être déterminée. Les fortes concentrations en saccharose et inositol inhibent la formation de racines et les embryons doivent être transférés sur un milieu d'enracinement avant la transplantation en serre. Seulement 10 à 20 p. 100 des petits embryons (moins de $2 \mathrm{~mm}$ au moment de la mise en culture) et au plus $59 \mathrm{p}$. 100 des gros embryons (plus de $2 \mathrm{~mm}$ au moment de la mise en culture) ont donné des plantes adultes à l'issue de la culture in vitro.

Mots clés additionnels : Culture d'embryons, tournesol, culture in vitro, Helianthus annuus $L$.

(1) Cooperative investigations of the South Dakota Agricultural Experiment Station and USDA-ARS-NCR, Brookings, South Dakota 57007. Journal Series No. 2029.

(2) This paper reports the results of research only. Mention of a trademark, proprietary product, or vendor does not constitute a guarantee or warranty of the product by the U.S. Department of Agriculture and does not imply its approval to the exclusion of other products or vendors that may also be suitable.

$\left({ }^{3}\right)$ Chargée de Recherches, I.N.R.A., France ; Associate Professor, Dept. of Plant Science; Research Plant Physiologist, USDA-ARSNCR, respectively.

\section{INTRODUCTION}

The wild Helianthus species are of considerable interest as a source of genetic variation for economically important characters in the improvement of the cultivated sunflower (Helianthus annuus L.). Species that are resistant to several diseases and pests attacking sunflower (ROGERS et al., 1982) and have high oil content or quality (FICK et al., 1976 ; THOMPSON et al., 1978) have been identified. 
Several attempts to hybridize $H$. annuus with the other Helianthus species have been made, but most of them with only limited success (WHELAN, 1978). Embryo culture has been proposed as a tool for the rescue of the embryo before its abortion (CHANDLER, 1976) and has been successfully used in several cases (CHANDleR \& BEARD, 1983 ; CHANDLER \& JAN, 1983). For some of the most interesting crosses, however, CHANDLER (1976) failed to produce interspecific hybrids through embryo culture. Thus, the vast reservoir provided by the Helianthus species will remain partially out of reach of breeders unless a more successful method of crossing sunflower with other Helianthus species is developed. Our overall purpose is to develop such in vitro techniques that any desirable interspecific hybrid within the genus could be produced and applications to a breeding program could follow. To begin this work, for a better understanding of the basic needs and development of normal embryos, factors controlling in vitro growth and development of sunflower embryos ranged in age from 2 to 14 after anthesis were investigated.

\section{MATERIALS AND METHODS}

\section{A. Stocks and culture conditions}

Six inbred lines of $H$. annuus were used : two malesterile lines (cms HA 99 and Indiana - $1 \mathrm{cms}$ noted cms Ind in this paper), one maintainer (HA 99, noted B 99 in this paper), and three restorers (RHA 274, RHA 275, RHA 297). These six lines are among the most used in sunflower breeding programs in USA and are likely to be chosen as parents of crosses with other Helianthus species. In addition, a native population of $H$. annuus harvested in South Dakota (SD) during summer and fall 1982 was used. Plants were field grown on Vienna loam (Udic Haploborolls, fine loamy, mixed) during the summer of 1983. During the winter of 1983-1984, plants were greenhouse grown in a $1: 1: 1$ peat moss : sand : soil mixture. The air temperature of the greenhouse was maintained at $22{ }^{\circ} \mathrm{C} \pm 4{ }^{\circ} \mathrm{C}$. Photoperiod was $16 \mathrm{~h}$ with supplemental lighting provided by high pressure sodium lamps $\left(100 \mu \mathrm{Em}^{-2} \mathrm{~s}^{-1}\right.$, photosynthetically active radiation).

\section{B. Crosses}

Male sterile plants were bagged before anthesis and pollinated either with the corresponding B-line pollen (sib considered as self pollination) or bulk pollen from the restorer lines (cross pollination). The 8 outermost floret rings were pollinated when the stigmata were receptive and the following 8 rings removed. The central rings were later pollinated by the same pollen when their stigmata were receptive. Heads of maintainer and restorer lines were pollinated using the techniques of DEDIO \& PUTT (1980). Heads of the wild population were not bagged but were left open to natural pollination.

\section{Embryo features}

Embryo age was expressed as days from the day of pollination. Embryo size was a direct measure taken with a rule graduated in $\mathrm{mm}$ after plating the embryos. Embryo shapes were defined according to NEwCOMB (1973). Embryos less than 3 days old were generally less than $0.1 \mathrm{~mm}$ in size (fig. 1). Up to 7 to 10 days old ( 3 to $5 \mathrm{~mm}$ ) embryos were floating in the embryo sac despite having developed cotyledons; 14 day old embryos (about $7 \mathrm{~mm}$ ) had fully developed cotyledons and endosperms which were nearly resorbed.

\section{Embryo culture}

Ovaries were surface sterilized in $0.5 \% \mathrm{NaOCl}$ for 5 to $15 \mathrm{mn}$, blotted on sterile filter paper and then submerged in $70 \%$ ethanol for 1 to $3 \mathrm{mn}$. Embryos were excised and plated on $60 \mathrm{ml}$ of $8 \%$ agar medium in $100 \times 20 \mathrm{~mm}$ Petri dishes sealed with tape. All media were adjusted to $\mathrm{pH} 6.0$ and sterilized in an autoclave at $15 \mathrm{psi}$ for $30 \mathrm{mn}$. Petri dishes were maintained at $25^{\circ} \mathrm{C}, 16 \mathrm{~h}$ photoperiod under cool white fluorescent light of about $100 \mu \mathrm{Em}^{-2} \mathrm{~s}^{-1}$ photosynthetically active radiation after plating.

From 3 days of age (about $0,1 \mathrm{~mm}$ ) to 7 days of age (about $4 \mathrm{~mm}$ ) embryos were floating inside the embryo sac and were excised under the dissecting microscope. Embryos younger than 3 days old were not used. Embryos 10 days old or more could be excised without the aid of the microscope. The embryos swelled almost immediately after plating; within 2 to 4 days, the cotyledons began to turn green and to enlarge rapidly. This was considered to be normal in vitro growth and development, and only the embryos that showed such «normal » development were included in survival scores. Embryos that either died or developed abnormally into calluses were counted as failure to survive. Scoring was performed every other day.

Two basic media were used : HD, a modification of MURASHIGE and SKOOG medium (MURASHIGE \& SKOOG, 1962) defined by HUFF \& DYBING (1980), and B5 (GAMBORG et al., 1968). The modification of B5 defined by CHANDLER (1976) is referred to as B5 + AA in this paper. Compositions of all media are given in table 1 . By changing one chemical at a time, new media were derived from both HD and B5 in order to allow direct comparison between them : each time HD was equated to B5 (table 1).

Rooting rarely occurred on any of these media. Therefore, embryos were transferred to a rooting medium which consisted of HD without inositol and with a sucrose content of $1 \%$. Conditions of culture during rooting remained the same as for embryo growth. Transfer to the rooting medium was performed when by intuitive standards embryos appeared to be well shaped, fully developed, and vigorous enough to survive. Embryos larger than $2 \mathrm{~mm}$ with developed cotyledons at plating were transferred to the rooting medium 5 days later. Embryos less than $2 \mathrm{~mm}$ long were generally transferred 1 to 2 weeks after plating. Shoot elongation also occurred on the rooting medium. 
TABLE 1

Composition of media.

Composition des milieux.

\begin{tabular}{|c|c|c|c|c|}
\hline \multirow[t]{2}{*}{ Medium $^{\mathrm{a}}$} & \multicolumn{2}{|c|}{$\mathrm{mM} / 1$} & \multicolumn{2}{|c|}{$\mathrm{g} / 1$} \\
\hline & $\mathrm{NH}_{4}$ & $\mathrm{NO}_{3}$ & Inositol & Sucrose \\
\hline B5 & 2 & 25 & 4.0 & 90 \\
\hline $\mathrm{B} 5+\mathrm{AA}$ & 2 & 25 & 4.0 & 90 \\
\hline B5-I & 2 & 25 & 0.1 & 90 \\
\hline B5-S & 2 & 25 & 4.0 & 20 \\
\hline B5-I-S & 2 & 25 & 0.1 & 20 \\
\hline $\mathrm{B} 5-\mathrm{NO}_{3}{ }^{\mathrm{b}}$ & 27 & 0 & 4.0 & 90 \\
\hline $\mathrm{B} 5-\mathrm{NH}_{4}{ }^{\mathrm{C}}$ & 0 & 27 & 4.0 & 90 \\
\hline $\mathrm{HD}^{\mathrm{a}}$ & 25 & 50 & 0.1 & 20 \\
\hline $\mathrm{HD}+\mathrm{I}$ & 25 & 50 & 4.0 & 20 \\
\hline $\mathrm{HD}+\mathrm{S}$ & 25 & 50 & 0.1 & 90 \\
\hline $\mathrm{HD}+\mathrm{V}^{\mathrm{d}}$ & 25 & 50 & 0.1 & 20 \\
\hline $\mathrm{HD}+\mathrm{I}+\mathrm{V}+\mathrm{S}$ & 25 & 50 & 4.0 & 90 \\
\hline $\mathrm{HD}+3 \mathrm{~S}$ & 25 & 50 & 0.1 & 270 \\
\hline $\mathrm{HD}-\mathrm{NH}_{4} \mathrm{c}$ & 0 & 27 & 0.1 & 20 \\
\hline $\mathrm{HD}-\mathrm{NO}_{3}{ }^{\mathrm{b}}$ & 27 & 0 & 0.1 & 20 \\
\hline $\mathrm{HD}\left(\mathrm{NH}_{4} \mathrm{SO}_{4}\right)^{e}$ & 2 & 25 & 0.1 & 20 \\
\hline $\mathrm{HD}\left(\mathrm{NH}_{4} / \mathrm{NO}_{3}\right)^{\mathrm{f}}$ & 1 & 26 & 0.1 & 20 \\
\hline HD $(\text { low N})^{g}$ & 1 & 26 & 0.1 & 20 \\
\hline $\mathrm{HD}+\mathrm{S}($ low $\mathrm{N})$ & 1 & 26 & 0.1 & 90 \\
\hline HD rooting medium & 25 & 50 & 0.0 & 10 \\
\hline
\end{tabular}

a Element concentration in $\mathrm{B} 5$ in $\mathrm{mM}: \mathrm{Ca}=3 ; \mathrm{Cl}=6 ; \mathrm{So}_{4}=2 ; \mathrm{Fe}=0.085 ; \mathrm{B}=0.097 ; \mathrm{Co}=0.000105 ; \mathrm{Mo}=0.00103 ; \mathrm{K}=25$; $\mathrm{Mg}=1 ; \mathrm{Mn}=0.059 ; \mathrm{Zn}=0.007 ; \mathrm{PO}_{4}=1.25 ; \mathrm{Na}=1.25$. HD is similar except $: \mathrm{K}=27 ; \mathrm{Mg}=2 ; \mathrm{Mn}=0.095 ; \mathrm{Zn}=0.03 ;$ $\mathrm{PO}_{1}=1.25 ; \mathrm{Na}=0$ in $\mathrm{mM}$.

Vitamin concentration in $\mathrm{B} 5$ versus $\mathrm{HD}$ in $\mathrm{mg} / \mathrm{l}$ : Thiamine $\mathrm{HCl}=10$ vs 0.4 . Pyridoxine $\mathrm{HCl}=1$ vs $0.5 ;$ Nicotinic acid $=1$ vs 0.5 . Hormone concentration in both $\mathrm{B} 5$ and $\mathrm{HD}$ in $\mathrm{mg} / \mathrm{I}: \mathrm{NAA}=1$.

B5 $+\mathrm{AA}=\mathrm{B} 5$ with added amino acids $; \mathrm{B} 5-\mathrm{I}=\mathrm{B} 5$ with reduced inositol ; B5-S $=\mathrm{B} 5$ with reduced sucrose ; B5-I-S $=$ B5 with reduced inositol and sucrose ; HD $+\mathrm{I}=\mathrm{HD}$ with extra inositol ; HD $+\mathrm{S}$ with extra sucrose ; $\mathrm{AA}=$ amino acid ; $\mathrm{I}=$ inositol ; $\mathrm{S}=$ sucrose ; $\mathrm{V}=$ vitamins $; \mathrm{N}=$ nitrogen.

b Nitrogen provided as glutamine.

c Nitrogen provided as $\mathrm{KNO}_{3}$ and $\mathrm{CaNO}_{3}$.

d $\mathrm{HD}+\mathrm{V}$ and $\mathrm{B} 5$ had the same vitamin composition.

e $\mathrm{HD}\left(\mathrm{NH}_{4} \mathrm{SO}_{4}\right)$ and $\mathrm{B} 5$ had the same nitrogen composition.

f $\mathrm{HD}\left(\mathrm{NH}_{4} / \mathrm{NO}_{3}\right)$ had the same ratio $\mathrm{NH}_{4} / \mathrm{NO}_{3}$ than $\mathrm{B}$.

$\mathrm{g}$ HD (low $\mathrm{N}$ ) had the same quantity of total nitrogen than $\mathrm{B} 5$.

When both shoots and roots were about $1 \mathrm{~cm}$ long, the plantlets were transplanted into vermiculite in the greenhouse. Plantlets were watered once a week with HOAGLAND \& ARNON's No. 1 nutrient solution (1950) and grown until flowering.

\section{RESULTS AND DISCUSSION}

Of the many factors that can affect in vitro development of embryos, we investigated : 1) embryo origin (location on the head and pollen source); 2) embryo developmental stage (age, size, shape), and 3) media composition.

\section{A. Embryo origins and in vitro development}

In vitro survival of embryos of cms HA 99 derived from self pollination or cross pollination was not affected by location of the embryo on the sunflower head. When both crosses were averaged, survival percentages of embryos excised from outside versus inside rings were $15 \%(24 / 160)$ and $17 \%(21 / 120)$ respectively. Besides, embryos derived from self pollination or cross pollination of cms HA 99 showed similar percentages of in vitro survival, $42 \%$ $(144 / 340)$ and $39 \%(134 / 340)$ respectively. Likewise, the number of embryos arising from self-, cross-, or open pollination of 3 lines (RHA 274, RHA 297, B 99) that developed in vitro were 159/230 (69\%), $168 / 250(67 \%), 215 / 308(70 \%)$, respectively. From these results, we concluded that all intraspecific embryos arising from the same female parent could be pooled per age and that each head could be used as a replicate. Since embryos of different genotypic origin were pooled together, results were assumed to be representative of $H$. annuus, although we recognize that, if investigated, ability to develop in vitro may vary within this species.

\section{B. Developmental stage and in vitro development}

In our earliest experiments (data not shown) we observed that in vitro development dramatically changed with embryo age. But age alone appeared not to be a reliable character, since embryos of the same 
age could differ in size and shape depending on weather conditions. For example, 6 day old embryos were less than $1 \mathrm{~mm}$ long and heart shaped when days during and after pollination were cool and cloudy whereas 4 day old embryos grown under bright and sunny days were about the same size and shape. Therefore, we decided to define embryo developmental stage according to size and shape rather than age. The various associations of size, shape, and age used to classify the embryos are shown in figure 1 . The double arrow under each embryo indicates the range of ages for which it has been observed.

As described in table 2 , in vitro behavior was influenced by embryo size and shape. Percentage of embryo survival on $\mathrm{B} 5+\mathrm{AA}$ and $\mathrm{B} 5$ steadily increased as the embryos' initial size increased from $0.1 \mathrm{~mm}$ (round shaped) to $0.5 \mathrm{~mm}$ (heart shaped). Survival of all embryos larger than $0.5 \mathrm{~mm}$ and more developed than heart shaped was close to $100 \%$. Growth on HD was even more dependent on embryo size and shape. Embryos less than $2 \mathrm{~mm}$ long and without fully developed cotyledons did not grow at all on HD. The critical size and shape for embryo survival on HD were $2 \mathrm{~mm}$ long and fully developed cotyledons, respectively. We attributed the differences in embryo survival on the 3 media to failure of the media to meet the embryos' requirements at the various developmental stages.

\section{Media composition and in vitro development}

For a number of plant species, adding amino acids to the medium improved embryo growth and development (RAGHAVAN, 1980). CHANDLER (1976) successfully used B5 + AA, the B5 medium obtained after addition of 5 amino acids (alanine, glutamine, serine, tryptophane, cysteine) to grow embryos arising from crosses between Helianthus species. We were able to confirm this result for intraspecific sunflower embryos

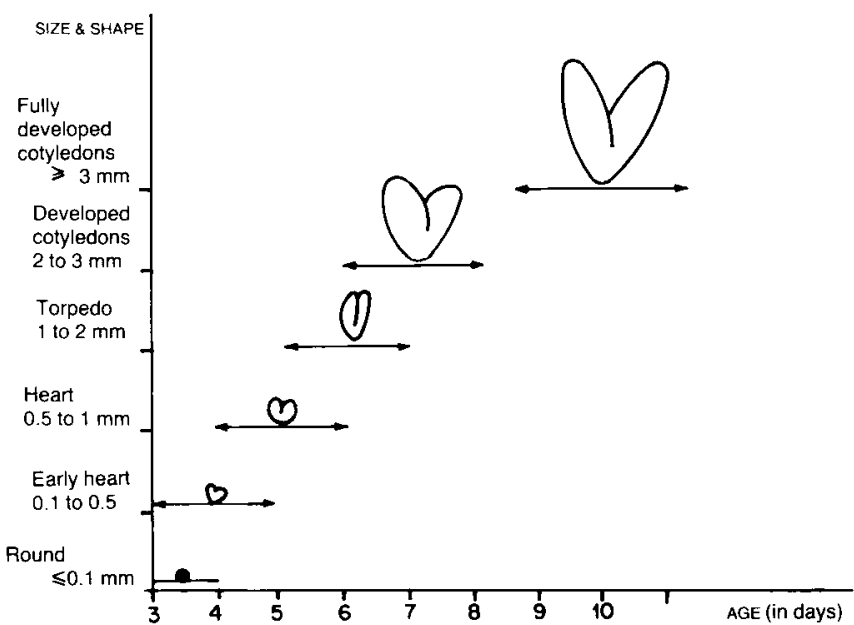

Figure 1

Embryo developmental stages.

Stades de développement de l'embryon.

but were also able to grow them as successfully on B5 (table 2). Since we did not find that amino acids were essential to survival of intraspecific sunflower embryos we decided to use only B5.

Unlike B5, HD was unable to meet the requirements of young embryos smaller than $2 \mathrm{~mm}$ long and without fully developed cotyledons. The differences between HD and B5 were mainly in their nitrogen source, and vitamin and carbohydrate compositions. HD contained $75 \mathrm{mM}$ nitrogen, one third from $\mathrm{NH}_{4}$, two thirds from $\mathrm{NO}_{3}$. B5 contained a third as much nitrogen $(27 \mathrm{mM})$ of which $92 \%$ was from $\mathrm{NO}_{3}$. When the total nitrogen content in $\mathrm{HD}$ was reduced to $27 \mathrm{mM}$ (HD (low N)) or when the percentage of the $\mathrm{NH}_{4}$ was decreased to $8 \%\left[\mathrm{HD}\left(\mathrm{NH}_{4} / \mathrm{NO}_{3}\right)\right]$ or both [HD $\left.\left(\mathrm{NH}_{4} \mathrm{SO}_{4}\right)\right]$, the number of small $(<2 \mathrm{~mm})$ embryos which grew on these 3 media only slightly

TABLE 2

In vitro survival of $\mathrm{H}$. annuus wild population embryos as related to culture medium and stage of embryo development at time of plating. Survie in vitro des embryons d'une population sauvage d'H. annuus en fonction du milieu de culture et du stade de développement de l'embryon au moment de la mise en culture.

\begin{tabular}{|c|c|c|c|c|c|c|c|c|c|c|c|c|}
\hline \multirow{3}{*}{ Medium $^{\mathrm{a}}$} & \multicolumn{10}{|c|}{ Stages of development ${ }^{b}$} & \multirow{2}{*}{\multicolumn{2}{|c|}{ Total }} \\
\hline & \multicolumn{2}{|c|}{$\begin{array}{l}0.1 \mathrm{~mm} \\
\text { Round } \\
\text { shaped }\end{array}$} & \multicolumn{2}{|c|}{$\begin{array}{l}0.1 \text { to } 0.5 \mathrm{~mm} \\
\text { Early heart } \\
\text { shaped }\end{array}$} & \multicolumn{2}{|c|}{$\begin{array}{l}0.5 \text { to } 1 \mathrm{~mm} \\
\text { Heart } \\
\text { shaped }\end{array}$} & \multicolumn{2}{|c|}{$\begin{array}{l}1 \text { to } 2 \mathrm{~mm} \\
\text { Torpedo } \\
\text { shaped }\end{array}$} & \multicolumn{2}{|c|}{$\begin{array}{l}2 \text { to } 4 \mathrm{~mm} \\
\text { Developed } \\
\text { cytolydeons }\end{array}$} & & \\
\hline & ratio $^{c}$ & $\%$ & ratio & $\%$ & ratio & $\%$ & ratio & $\%$ & ratio & $\%$ & ratio & $\%$ \\
\hline $\mathrm{B} 5+\mathrm{AA}$ & $4 / 49$ & 8 & $27 / 47$ & 57 & $33 / 37$ & 89 & $50 / 51$ & 98 & $72 / 73$ & 99 & $186 / 257$ & 72 \\
\hline B5 & $6 / 49$ & 12 & $30 / 51$ & 59 & $34 / 38$ & 89 & $43 / 48$ & 90 & $61 / 61$ & 100 & $174 / 247$ & 70 \\
\hline $\mathrm{HD}$ & $0 / 36$ & 0 & $0 / 49$ & 0 & $0 / 38$ & 0 & $1 / 48$ & 2 & $66 / 73$ & 90 & $67 / 244$ & 27 \\
\hline B5-S & $0 / 49$ & 0 & $4 / 49$ & 8 & $19 / 40$ & 47 & $19 / 45$ & 42 & $64 / 67$ & 95 & $106 / 250$ & 42 \\
\hline B5-I-S & $0 / 48$ & 0 & $0 / 47$ & 0 & $3 / 32$ & 9 & $15 / 49$ & 31 & $65 / 69$ & 94 & $83 / 245$ & 34 \\
\hline $\mathrm{HD}+\mathrm{S}$ & $4 / 45$ & 9 & $8 / 48$ & 17 & $28 / 42$ & 67 & $30 / 46$ & 65 & $53 / 70$ & 76 & $123 / 251$ & 49 \\
\hline $\mathrm{HD}+\mathrm{S}($ low $N)$ & $3 / 33$ & 9 & $18 / 49$ & 37 & $33 / 37$ & 89 & $47 / 50$ & 94 & $63 / 64$ & 98 & $164 / 233$ & 70 \\
\hline B5-I & $7 / 47$ & 15 & $21 / 51$ & 41 & $34 / 38$ & 89 & $45 / 47$ & 96 & $72 / 72$ & 100 & $179 / 255$ & 70 \\
\hline Iotal & $24 / 356$ & 7 & $108 / 391$ & 28 & $184 / 302$ & 61 & $250 / 384$ & 65 & $516 / 549$ & 94 & $1082 / 1982$ & 55 \\
\hline
\end{tabular}

a See table 1.

b See figure 1 .

c Number of embryos that survived (alive + cotyledon greening and enlargement)/total number of embryos plated. 
increased and never reached the percentage obtained on $\mathrm{B} 5$ (table 3 ). When all the nitrogen was provided as $\mathrm{NH}_{4}\left(\mathrm{HD}-\mathrm{NO}_{3}\right)$ or as $\mathrm{NO}_{3}\left(\mathrm{HD}-\mathrm{NH}_{4}\right)$ we did not observe significant differences in the percentages of young embryos that survived on either of the 5 media derived from HD. Since similar results were obtained from $\mathrm{HD}-\mathrm{NO}_{3}$ and $\mathrm{HD}-\mathrm{NH}_{4}$ on the one hand and $\mathrm{B} 5$, $\mathrm{B} 5-\mathrm{NO}_{3}$ and $\mathrm{B} 5-\mathrm{NH}_{4}$ on the other hand (table 3), neither form of nitrogen could be concluded to be superior to the other one in terms of embryo survival. Slightly higher percentages of embryo survival obtained on $\mathrm{B} 5-\mathrm{NO}_{3}$ are misleading since embryos were thinner, less vigorous and almost abnormal and could have been counted as failure to survive. The high content of $\mathrm{Cl}$ ions from $\mathrm{KCl}$ which was used to restore the potassium content in $\mathrm{B} 5-\mathrm{NO}_{3}$ could be the cause of the low survival on this media. This experiment should be repeated using another potassium source before any definitive conclusion can be made about the $\mathrm{NH}_{4}$ form. There may be some advantage to $\mathrm{B} 5-\mathrm{NH}_{4}$ which allowed direct rooting, but embryos that survived on $\mathrm{B} 5$ and $\mathrm{B} 5-\mathrm{NO}_{3}$ were not transferred to the rooting medium and the eventual advantage of direct rooting remains to be evaluated. However, neither the quantity nor the form of nitrogen can explain the differences in embryo survival observed between HD and B5.

The high vitamin content of B5 was not responsible for the higher percentages of embryos that survived on it. Although $\mathrm{B} 5$ and $\mathrm{HD}+\mathrm{V}$ had equal vitamin content, as few embryos smaller than $2 \mathrm{~mm}$ survived on $\mathrm{HD}+\mathrm{V}$ as on HD.

B5 also contained 40 times more inositol and 4.5 times more sucrose than HD. There was no beneficial effect of the large amount of inositol in B5 on the in vitro growth of small sunflower embryos. By reducing 40 times the inositol content in B5 (B5-I), there was no significant drop of the embryo survival nor was survival improved to the same level as in B5 by increasing 40 times the inositol content in HD $(\mathrm{HD}+\mathrm{I})$ (table 4).

Interestingly, sorbitol which is as inositol a major constituent of coconut milk (RAGHAVAN, 1976) could be used as a substitute for inotisol ; B5 sorbitol was nearly as good as B5 and B5-I. It appeared that neither inositol nor sorbitol could account for the superiority of B5 on sunflower embryo survival.

As shown in tables 2 and 4, in vivo growth was strongly dependent on sucrose content. When the sucrose content in B5 was reduced to $2 \%$, which is the concentration in $\mathrm{HD}$, the percentages of embryo survival on B5-S and B5-S-I sharply decreased and for embryos smaller than $0.5 \mathrm{~mm}$ dropped to the level observed on HD (table 2). Sunflower embryos required the high osmotic pressure provided by high sucrose content to develop and grow in vitro as was found for many other plant species (NARAYANASWAMI \& NORSTOG, 1964 ; RAGHAVAN, 1976). However, not as many embryos grew on $\mathrm{HD}+\mathrm{S}$ as on $\mathrm{B} 5$, though both media contained $9 \%$ sucrose, and more grew on

TABLE 3

In vitro survival of sunflower embryos as related to nitrogen content of the medium.

Survie in vitro des embryons de tournesol en fonction de la composition azotée du milieu.

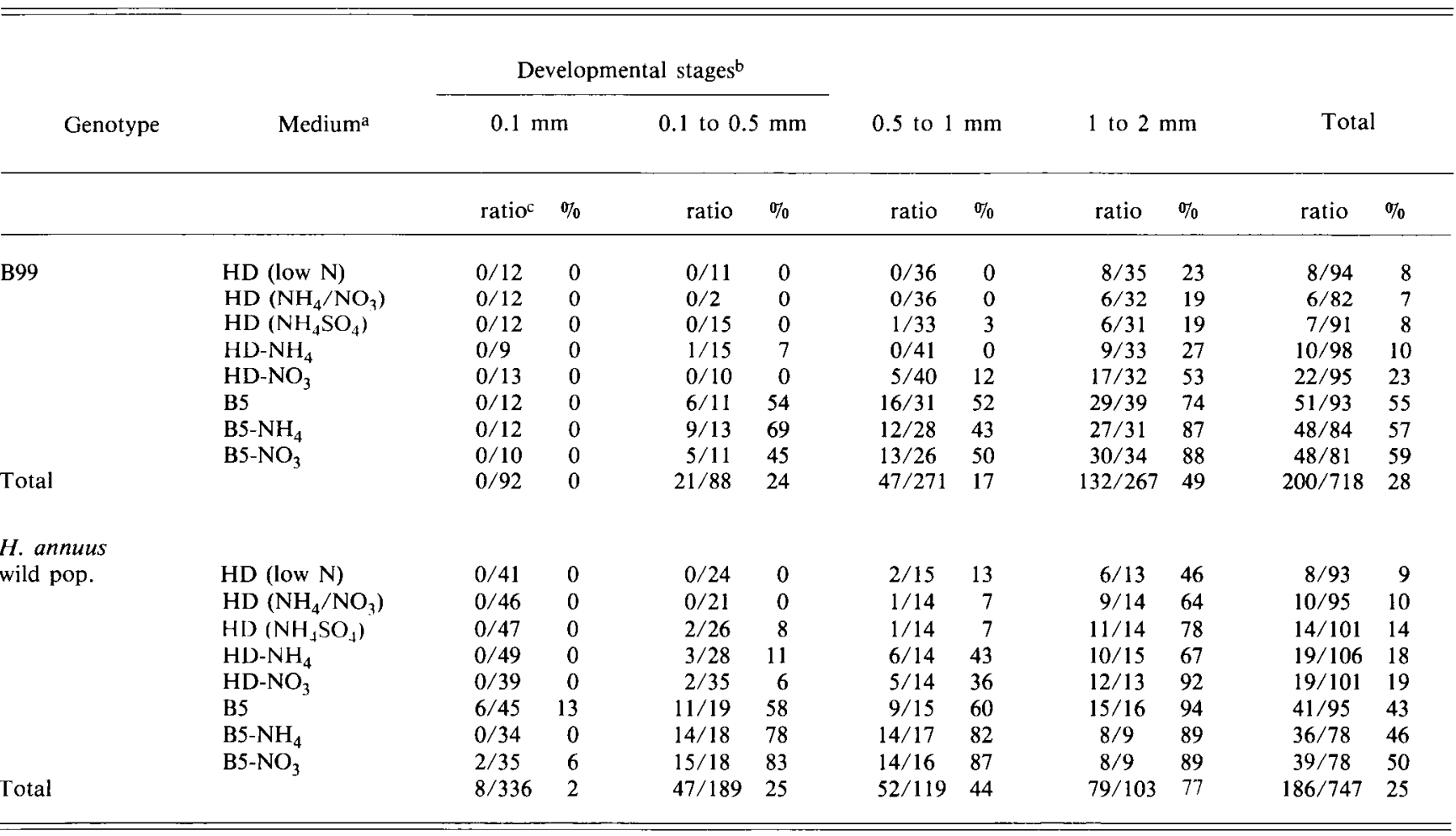

a See table 1.

b See figure 1.

c Number of embryos that survived (alive + cotyledon greening and enlargement)/total number of embryos plated. 
TABLE 4

In vitro survival of sunflower embryos as related to carbohydrate content of the medium.

Survie in vitro des embryons de tournesol en fonction de la teneur en carbohydrate du milieu.

\begin{tabular}{|c|c|c|c|c|c|c|c|c|c|c|c|}
\hline \multirow{3}{*}{ Genotype } & \multirow{3}{*}{ Mediuma $^{a}$} & \multicolumn{8}{|c|}{ Developmental stages $b$} & \multirow{2}{*}{\multicolumn{2}{|c|}{$(2-3 \mathrm{~mm})$}} \\
\hline & & \multicolumn{2}{|c|}{$(0.1 \mathrm{~mm})$} & \multicolumn{2}{|c|}{$(0.1-0.5 \mathrm{~mm})$} & \multicolumn{2}{|c|}{$(0.5-1 \mathrm{~mm})$} & \multicolumn{2}{|c|}{$(1-2 \mathrm{~mm})$} & & \\
\hline & & ratio & $\%$ & ratio & $\%$ & ratio & $0 \%$ & ratio & $\%$ & ratio & $\%$ \\
\hline Cms HA 99 & $\begin{array}{l}H D \\
H D+V \\
H D+I \\
H D+S \\
H D+I+S+V \\
\text { B5 } \\
\text { B5-I } \\
\text { B5-S }\end{array}$ & $\begin{array}{l}0 / 57 \\
0 / 59 \\
0 / 58 \\
0 / 40 \\
0 / 59 \\
0 / 58 \\
0 / 42 \\
0 / 32\end{array}$ & $\begin{array}{l}0 \\
0 \\
0 \\
0 \\
0 \\
0 \\
0 \\
0\end{array}$ & $\begin{array}{l}0 / 41 \\
0 / 41 \\
0 / 30 \\
0 / 42 \\
0 / 30 \\
0 / 30 \\
0 / 41 \\
0 / 31\end{array}$ & $\begin{array}{l}0 \\
0 \\
0 \\
0 \\
0 \\
0 \\
0 \\
0\end{array}$ & $\begin{array}{r}0 / 62 \\
0 / 68 \\
17 / 60 \\
2 / 63 \\
11 / 70 \\
25 / 52 \\
43 / 70 \\
17 / 49\end{array}$ & $\begin{array}{r}0 \\
0 \\
28 \\
3 \\
16 \\
48 \\
61 \\
35\end{array}$ & $\begin{array}{r}5 / 42 \\
1 / 37 \\
3 / 43 \\
16 / 41 \\
21 / 48 \\
38 / 44 \\
46 / 47 \\
44 / 56\end{array}$ & $\begin{array}{r}12 \\
3 \\
7 \\
39 \\
44 \\
86 \\
98 \\
78\end{array}$ & & \\
\hline Cms Ind & $\begin{array}{l}\mathrm{HD} \\
\mathrm{HD}+\mathrm{V} \\
\mathrm{HD}+\mathrm{I} \\
\mathrm{HD}+\mathrm{S} \\
\mathrm{HD}+\mathrm{I}+\mathrm{S}+\mathrm{V} \\
\mathrm{B} 5 \\
\mathrm{~B} 5-\mathrm{I} \\
\mathrm{B} 5-\mathrm{S} \\
\text { B5 sorbitol }\end{array}$ & $\begin{array}{l}- \\
- \\
- \\
- \\
- \\
- \\
-\end{array}$ & & $\begin{array}{l}- \\
- \\
- \\
- \\
- \\
- \\
-\end{array}$ & & $\begin{array}{c}0 / 12 \\
0 / 12 \\
0 / 12 \\
0 / 12 \\
- \\
11 / 12 \\
12 / 12 \\
11 / 12 \\
3 / 12\end{array}$ & $\begin{array}{r}0 \\
0 \\
0 \\
0 \\
- \\
92 \\
100 \\
92 \\
25\end{array}$ & $\begin{array}{r}1 / 15 \\
2 / 15 \\
2 / 15 \\
0 / 15 \\
15 / 15 \\
15 / 15 \\
15 / 15 \\
15 / 15 \\
13 / 15\end{array}$ & $\begin{array}{r}7 \\
13 \\
13 \\
0 \\
100 \\
100 \\
100 \\
100 \\
87\end{array}$ & $\begin{array}{r}11 / 15 \\
13 / 15 \\
12 / 15 \\
0 / 15 \\
15 / 15 \\
15 / 15 \\
15 / 15 \\
15 / 15 \\
15 / 15\end{array}$ & $\begin{array}{r}73 \\
87 \\
80 \\
0 \\
100 \\
100 \\
100 \\
100 \\
100\end{array}$ \\
\hline
\end{tabular}

a See table 1 .

b See figure 1 .

c Number of embryos that survived (alive + cotyledon greening and enlargement)/total number of embryos plated.

$\mathrm{HD}+\mathrm{S}($ low $\mathrm{N})$ than on $\mathrm{HD}+\mathrm{S}$ (table 2). Thus, the sucrose content did not completely explain the superiority of B5 to HD. It also seemed necessary to reduce the nitrogen supply. The desired balance between nitrogen and inositol + sucrose content was in B5: $\mathrm{C} / \mathrm{N}=10.55$. Sunflower embryos smaller than $2 \mathrm{~mm}$ required high osmolarity associated with low nitrogen concentration in contrast to embryos of soybean, cotton and barley for which increased concentration of $\mathrm{NH}_{4}$ successfully replaced high osmolarity (NORSTOG, 1977). On HD $+3 S$ which had the same $C / N$ ratio as $B 5$ but 3 times more sucrose $(27 \%)$ nothing grew. Because $\mathrm{HD}+3 \mathrm{~S}$ was never contaminated either by fungi or bacteria we assumed the osmotic pressure was too high to allow those organisms to survive.

However, for the embryos in early stages, B5 remained superior to $H D+S$ (low $N$ ). Since all other constituents have been investigated, the remaining difference can only be due to an overall superior balance or to the mineral nutrients. $\mathrm{HD}$ had the mineral composition of MURASHIGE \& SKOOG medium which was very similar to B5. But, RAGHAVAN (1976) reported better growth or development on one medium than on another because of differences in inorganic salt composition, and MONNIER (1978) found that the MS salt solution was toxic. Whether B5 mineral composition or its balance of nutrients enhanced in vitro survival of sunflower embryos, remains to be determined. Finally, although mineral nutrients and nutrient interaction may be involved, the high sucrose content $(9 \%)$ associated with low nitrogen concentration $(\mathrm{C} / \mathrm{N}=10.55)$ explained the superiority of B5 for the survival of sunflower embryos in early stages of development.
As observed by CHANDLER \& BEARD (1983) we found that high sucrose and inositol concentrations inhibited root formation. Therefore, inositol was deleted from the rooting medium and the sucrose content reduced to $1 \%$. Not all embryos transferred to the rooting medium formed roots. The ratio varied according to the initial embryo stage of development and the medium on which they were first grown (table 5). More embryos were lost following transfer into vermiculite in the greenhouse. The embryos which developed both shoots and roots on the first medium usually survived better in the greenhouse than those which had to be transferred to the rooting medium (table 5). However, the number of embryos which directly formed shoots and roots was so low that fewer adult plants were obtained than by using two media (first medium and rooting medium). In all cases, the number of adult plants produced through embryo culture remained low : only 10 to $20 \%$ of the embryos in early stages of development and, at most, $59 \%$ of the ones in late stages of development reached adult age (table 6 ).

\section{CONCLUSIONS}

The origin of sunflower embryos, location on the head, and source of intraspecific pollen, did not modify their in vitro behavior. The embryo requirements for in vitro growth varied according to their size and shape. A critical stage of development was defined by a $2 \mathrm{~mm}$ length and fully developed cotyledons. Depending on weather conditions, it was reached between the 5 th and 7 th day after pollination. 
TABLE 5

Number of embryos of $\mathrm{H}$. annuus wild population that formed roots ( $\left.{ }^{1}\right)$ and survived transfer in greenhouse (2).

Nombre d'embryons d'une population sauvage d'H. annuus qui forment des racines (l) et survivent au transfert en serre $\left({ }^{2}\right)$.

\begin{tabular}{|c|c|c|c|c|c|c|c|c|c|c|c|}
\hline \multirow{3}{*}{$\begin{array}{c}\text { Initial } \\
\text { Medium }^{\mathrm{a}}\end{array}$} & \multirow{3}{*}{$\begin{array}{c}\text { Response } \\
\text { Type }\end{array}$} & \multicolumn{10}{|c|}{ Stages of development ${ }^{b}$} \\
\hline & & \multicolumn{2}{|c|}{$0.1 \mathrm{~mm}$} & \multicolumn{2}{|c|}{0.1 to $0.5 \mathrm{~mm}$} & \multicolumn{2}{|c|}{0.5 to $1 \mathrm{~mm}$} & \multicolumn{2}{|c|}{1 to $2 \mathrm{~mm}$} & \multicolumn{2}{|c|}{2 to $4 \mathrm{~mm}$} \\
\hline & & (1) & (2) & (1) & (2) & (1) & $(2)$ & (1) & $(2)$ & (1) & $(2)$ \\
\hline $\mathrm{B} 5+\mathrm{AA}$ & $\begin{array}{l}\text { DR } \\
\text { IR }\end{array}$ & $\begin{array}{l}0 / 4 \\
2 / 4\end{array}$ & 2 & $\begin{array}{l}0 / 27 \\
6 / 27\end{array}$ & 5 & $\begin{array}{l}0 / 33 \\
2 / 33\end{array}$ & 1 & $\begin{array}{r}0 / 50 \\
28 / 50\end{array}$ & 17 & $\begin{array}{r}6 / 72 \\
38 / 72\end{array}$ & $\begin{array}{r}5 \\
22\end{array}$ \\
\hline B5 & $\begin{array}{l}\text { DR } \\
\text { IR }\end{array}$ & $\begin{array}{l}0 / 6 \\
3 / 6\end{array}$ & 0 & $\begin{array}{r}3 / 30 \\
14 / 30\end{array}$ & $\begin{array}{r}3 \\
11\end{array}$ & $\begin{array}{l}0 / 34 \\
9 / 34\end{array}$ & 5 & $\begin{array}{r}8 / 43 \\
14 / 43\end{array}$ & $\begin{array}{l}6 \\
8\end{array}$ & $\begin{array}{r}2 / 61 \\
28 / 61\end{array}$ & $\begin{array}{r}2 \\
26\end{array}$ \\
\hline HD & $\begin{array}{l}\text { DR } \\
\text { IR }\end{array}$ & $\begin{array}{l}0 / 0 \\
0 / 0\end{array}$ & & $\begin{array}{l}0 / 0 \\
0 / 0\end{array}$ & & $\begin{array}{l}0 / 0 \\
0 / 0\end{array}$ & & $\begin{array}{l}1 / 1 \\
0 / 1\end{array}$ & 1 & $\begin{array}{l}24 / 66 \\
21 / 66\end{array}$ & $\begin{array}{l}24 \\
13\end{array}$ \\
\hline B5-S & $\begin{array}{l}\text { DR } \\
\text { IR }\end{array}$ & $\begin{array}{l}0 / 0 \\
0 / 0\end{array}$ & & $\begin{array}{l}0 / 4 \\
2 / 4\end{array}$ & 2 & $\begin{array}{l}0 / 19 \\
2 / 19\end{array}$ & 0 & $\begin{array}{r}6 / 19 \\
11 / 19\end{array}$ & $\begin{array}{l}2 \\
1\end{array}$ & $\begin{array}{l}18 / 64 \\
22 / 64\end{array}$ & $\begin{array}{l}15 \\
17\end{array}$ \\
\hline B5-I-S & $\begin{array}{l}\text { DR } \\
\text { IR }\end{array}$ & $\begin{array}{l}0 / 0 \\
0 / 0\end{array}$ & & $\begin{array}{l}0 / 0 \\
0 / 0\end{array}$ & & $\begin{array}{l}0 / 3 \\
0 / 3\end{array}$ & & $\begin{array}{l}2 / 15 \\
3 / 15\end{array}$ & $\begin{array}{l}0 \\
0\end{array}$ & $\begin{array}{l}27 / 65 \\
23 / 65\end{array}$ & $\begin{array}{l}23 \\
18\end{array}$ \\
\hline $\mathrm{HD}+\mathrm{S}$ & $\begin{array}{l}\text { DR } \\
\text { IR }\end{array}$ & $\begin{array}{l}0 / 4 \\
3 / 4\end{array}$ & 3 & $\begin{array}{l}0 / 8 \\
1 / 8\end{array}$ & 1 & $\begin{array}{l}0 / 28 \\
9 / 28\end{array}$ & 3 & $\begin{array}{l}7 / 30 \\
6 / 30\end{array}$ & $\begin{array}{l}5 \\
5\end{array}$ & $\begin{array}{r}3 / 53 \\
32 / 53\end{array}$ & $\begin{array}{r}3 \\
24\end{array}$ \\
\hline $\mathrm{HD}+\mathrm{S}($ low $\mathrm{N})$ & $\begin{array}{l}\text { DR } \\
\text { IR }\end{array}$ & $\begin{array}{l}0 / 3 \\
0 / 3\end{array}$ & & $\begin{array}{l}0 / 18 \\
4 / 18\end{array}$ & 3 & $\begin{array}{l}1 / 33 \\
7 / 33\end{array}$ & $\begin{array}{l}0 \\
6\end{array}$ & $\begin{array}{l}12 / 47 \\
20 / 47\end{array}$ & $\begin{array}{l}10 \\
14\end{array}$ & $\begin{array}{r}8 / 63 \\
15 / 63\end{array}$ & $\begin{array}{l}7 \\
7\end{array}$ \\
\hline B5-I & $\begin{array}{l}\text { DR } \\
\text { IR }\end{array}$ & $\begin{array}{l}0 / 7 \\
4 / 7\end{array}$ & 0 & $\begin{array}{l}0 / 21 \\
8 / 21\end{array}$ & 4 & $\begin{array}{r}0 / 34 \\
12 / 34\end{array}$ & 7 & $\begin{array}{r}9 / 45 \\
20 / 45\end{array}$ & $\begin{array}{l}7 \\
8\end{array}$ & $\begin{array}{r}7 / 72 \\
34 / 72\end{array}$ & $\begin{array}{r}5 \\
28\end{array}$ \\
\hline
\end{tabular}

a See table 1.

b See figure 1 .

(1) Number of embryos which formed roots directly on the first medium (DR) or after transfer on the rooting medium (IR)/number of embryos that survived on the first medium.

(2) Number of embryos which survived transplantation into vermiculite in greenhouse.

TABLE 6

Adult plant yield through embryo culture from $\mathrm{H}$. annuus wild population.

Plantes adultes produites par la culture in vitro d'embryons d'une population sauvage d'H. annuus.

\begin{tabular}{|c|c|c|c|c|c|c|c|c|c|c|c|c|}
\hline \multirow{3}{*}{ Medium $^{\mathrm{a}}$} & \multicolumn{10}{|c|}{ Stages of development $b$} & & \\
\hline & \multicolumn{2}{|c|}{$0.1 \mathrm{~mm}$} & \multicolumn{2}{|c|}{0.1 to $0.5 \mathrm{~mm}$} & \multicolumn{2}{|c|}{0.5 to $1 \mathrm{~mm}$} & \multicolumn{2}{|c|}{1 to $2 \mathrm{~mm}$} & \multicolumn{2}{|c|}{2 to $4 \mathrm{~mm}$} & \multicolumn{2}{|l|}{ Total } \\
\hline & ratio $^{c}$ & $\%$ & ratio & $\%$ & ratio & $\%$ & ratio & $\%$ & ratio & $\%$ & ratio & $\%$ \\
\hline $\mathrm{B} 5+\mathrm{AA}$ & $2 / 49$ & 4 & $5 / 47$ & 11 & $1 / 37$ & 3 & $17 / 51$ & 33 & $27 / 73$ & 37 & $52 / 257$ & 20 \\
\hline B5 & $0 / 49$ & 0 & $14 / 51$ & 27 & $5 / 38$ & 13 & $14 / 48$ & 29 & $25 / 61$ & 41 & $58 / 247$ & 23 \\
\hline HD & $0 / 36$ & 0 & $0 / 49$ & 0 & $0 / 38$ & 0 & $1 / 48$ & 2 & $37 / 73$ & 51 & $38 / 244$ & 16 \\
\hline B5-S & $0 / 49$ & 0 & $2 / 49$ & 4 & $0 / 40$ & 0 & $3 / 45$ & 7 & $32 / 67$ & 48 & $37 / 250$ & 15 \\
\hline B5-I-S & $0 / 48$ & 0 & $0 / 47$ & 0 & $0 / 32$ & 0 & $0 / 49$ & 0 & $41 / 69$ & 59 & $41 / 245$ & 17 \\
\hline $\mathrm{HD}+\mathrm{S}$ & $3 / 45$ & 7 & $1 / 48$ & 2 & $3 / 42$ & 7 & $10 / 46$ & 22 & $27 / 70$ & 38 & $44 / 251$ & 17 \\
\hline $\mathrm{HD}+\mathrm{S}($ low $\mathrm{N})$ & $0 / 33$ & 0 & $3 / 49$ & 6 & $6 / 37$ & 16 & $24 / 50$ & 48 & $14 / 64$ & 22 & $47 / 233$ & 20 \\
\hline B5-I & $0 / 47$ & 0 & $4 / 51$ & 8 & $7 / 38$ & 18 & $15 / 47$ & 32 & $33 / 72$ & 46 & $59 / 255$ & 23 \\
\hline Total & $5 / 356$ & 1 & $29 / 391$ & 7 & $22 / 302$ & 7 & $84 / 384$ & 22 & $236 / 549$ & 43 & $376 / 1982$ & 19 \\
\hline
\end{tabular}

a See table 1 .

b See figure 1.

c Number of adult plants obtained/total number of embryos plated.

It ended the phase we define as premature during which sunflower embryos could only grow on a medium with high osmolarity. The same requirement was found for a number of other plant species (RAGHAVAN, 1976, NORSTOG, 1977). However, premature sunflower embryos also required a low nitrogen content, one-tenth of the sucrose + inositol content $(\mathrm{C} / \mathrm{N}=10.55)$. The preferred nitrogen form could not be determined. The effect of the mineral composition needs further investigations. Nevertheless, B5, as defined in this paper appeared to be the best medium to grow premature sunflower embryos. In case of interspecific embryos, abortion (if it happened) would more likely occur during the premature phase. JAN (pers. comm., 1984) observed that most interspecific hybrids aborted around the 5 th day. 
Since only 10 to $20 \%$ of the premature embryos grew on B5, formed roots on the rooting medium, and survived the transfer in a greenhouse, more improvements of our procedure for intraspecific sunflower embryos are necessary before it can be adapted and routinely used to produce interspecific hybrids with application to a breeding program.

Reçu le 24 septembre 1984. Accepté le 3 juin 1985.

\section{REFERENCES}

Chandler J. M., 1976. Sunflower interspecific hybridization using embryo culture. M. S. Thesis. Univ. of Calif., Davis, U.S.A.

Chandler J. M., Beard B. H., 1983. Embryo culture of Helianthus hybrids. Crop Sci., 23 (5), 1004-1007.

Chandler J. M., Jan C. C., 1983. Production of interspecific sunflower hybrids through tissue culture. Agronomy Abstr., 58.

Dedio W., Putt E. D., 1980. Sunflower in hybridization of crop plants. Fehr W. R., H. H. Wadley Ed. Am. Soc. of Agron., 631-642.

Fick G. N., Zimmer D. E., Thompson T. E., 1976. Wild species of Helianthus as a source of variability in sunflower breeding. Proc. lst Sunflower Forum, Fargo, ND, USA 4-5.

Gamborg O. L., Miller R. A., Ojima K., 1968. Nutrient requirements of suspension cultures of soybean root cells. Exp. Cell Res., 50, 151-158.

Huff A., Dybing C. D., 1980. Factors affecting shedding of flowers in soybean (Glycine max (L.) Merrill). J. Exp. Bot,, 31 (122), 751762.

Hoagland D. R., Arnon D. I., 1950. The water-culture method for growing plants without soil. Calif. Ag. Exp. Sta., Circ. 347, 1-32.

Murashige T., Skoog F., 1962. A revised medium for rapid growth and bio assays with tobacco tissue cultures. Physiol. Plant., 15, 473-497.

Monnier M., 1978. Culture of zygotic embryos. In : "Frontiers of Plant Tissue Culture, 1978 ». Int. Assoc. Plant Tissue Culture,
Univ. Calgary, Calgary, Alberta, Canada. T. A. Thorpe, Ed., 277286.

Narayanaswami S., Norstog K., 1964. Plant embryo culture. Bot. Rev., 30, 587-628.

Newcomb W., 1973. The development of the embryo sac of sunflower Helianthus annuus after fertilization. Can. J. Bot., 51, 879-890.

Norstog K., 1977. Embryo culture as a tool in the study of comparative and developmental morphology. In : W. R. Sharp, P. O. Larsen, E. F. Paddock, V. Raghavan : «Plant Cell and Tissue Culture. Principles and Applications», 179-202.'

Raghavan V., 1976. Experimental embryogenesis in vascular plants. Academic Press, 163-279.

Raghavan V., 1980. Perspectives in plant cell and tissue culture. Int. Rev. Cytol., 209-236.

Rogers C. E., Thompson T. E., Seiler G. J., 1982. Sunflower species of the United States. Publ. by The National Sunflower Association, Bismarck, ND.

Thompson T. E., Rogers C. E., Zimmerman D. C., Huang H. C., Whelan E. D. P., Miller J. F., 1978. Evaluation of Helianthus species for disease resistance and oil content and quality. Proc. 8th Int. Sunflower Conf., Minneapolis, MN, 501-509.

Whelan E, D. P., 1978. Cytology and interspecific hybridization. Agronomy, 19, 339-369. 